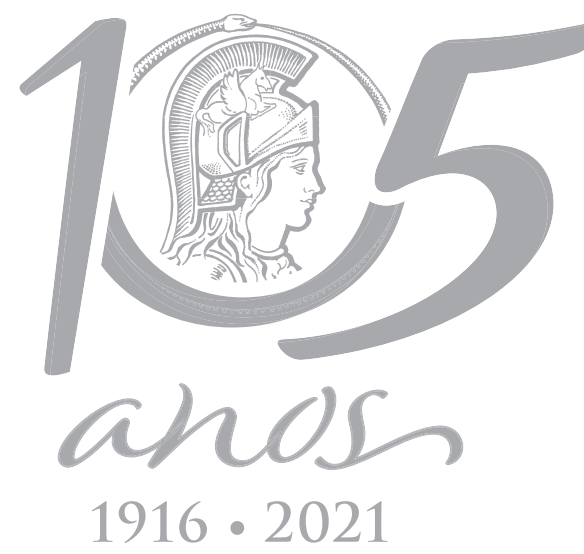

\title{
ECOSYSTEM
}

\section{Peripampasic Arc: a route of dispersion for lichens}

\author{
RENATO A. GARCÍA \& ALEJANDRO DEL PALACIO
}

\begin{abstract}
The Peripampasic Arc is a set of low mountains / hills that connects the Andes, as it scatters to the East forming mountainous areas of lower heights in north-eastern Argentina, with the Atlantic coastal range of the Serra do Mar in Brazil. Numerous studies proved its important biogeographic connection for plant and animal phylogenies, but no information of this pattern is known to lichens. The aim of this work is to establish if the dispersion route of the lichenbiota follows the previously known Peripampasic Arc. For this reason, a comparative study of each area regarding its similarities was analyzed, with emphasis on the biota of the Buenos Aires' Sierras. We quantified the similarity and $\beta$ diversity of 104 saxicolous lichens species. There was a strong similarity between the Sierra de la Ventana and Tandil biota, which in turn is linked to the biotas of Uruguay, the Pampean Sierras and the northwest of Argentina. The lack of subgroups in the Peripampasic Arc implies the arc acts as a functional unit of dispersion, which is the most likely cause for the present lichens' distribution.
\end{abstract}

Key words: Biota, linkages, lichens, peripampasic, south, diversity.

\section{INTRODUCTION}

The high Andean mountain range runs from North to South along the western side of South America, passing through western Argentina. In central and eastern Argentina, there is a set of scattered hills or 'Sierras' that form together with those of southern Uruguay, the so-called Peripampasic Arc (Figure 1, Frenguelli 1950). This Arc, owing to its unique biota, has attracted the interest of geologists and biologists (Darwin 1846, Cabrera 1938, Teruggi \& Kilmurray 1975) as it harbours a large number of endemic species (Crisci et al. 2001, Grela 2004, Pinto da Rocha et al. 2005, Aagesen et al. 2009). The component sierras of the Arc share various degrees of similarity in their biota, after millions of years of geographic separation (Ringuelet 1961, Acosta 1989, 1993, Mattoni \& Acosta 1997, Crisci et al. 2001) and they are important for biodiversity conservation from a biogeographic perspective (Szumik et al. 2007, Navarro et al. 2009, Nori et al. 2011). The rocky outcrops of the sierras are separated by forests or grasslands which provide at the same time isolation and connectivity (Aptroot \& James 2002, García 2018).

Hicken (1919) proposed that the biotas of the Andes and Brazil were connected through the Sierras Pampeanas and of Buenos Aires (Ventania y Tandilia) and the Southern Brazilian Highlands. De la Sota $(1967,1972,1973,1985)$ and de la Sota et al. (2004) proposed that the Sierras Pampeanas and of Buenos Aires constituted intermediary stations for Pteridophytes between the Andean and Pampean and the southernmost South American or Austral and Antarctic and Austral and southern Brazilian floras. They proposed four routes of dispersion (Austral-Antarctic, AustroBrazilian, Peripampasic and Andean). Arana et al. (2013) add new groups of Pteridophytes 


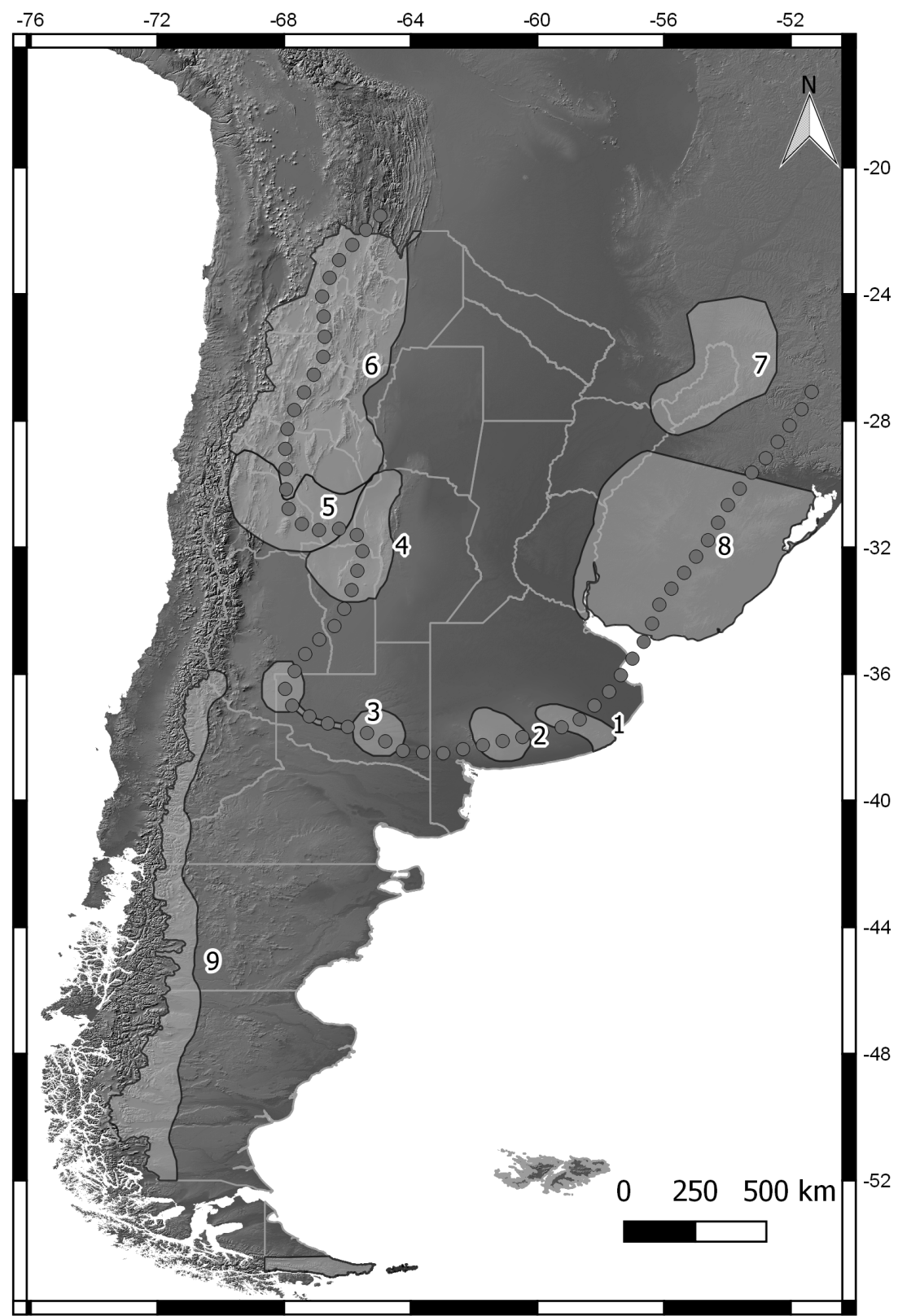

Figure 1. Peripampasic Arc

-. Study areas: 1-Tandilia;

2-Ventania; 3-San Rafael-

Mahuida; 4-Pampean

center's Hills; 5-Cuyan

Pampeans hills and

Precordillera; 6-North-

West; 7-North-East;

8-Uruguay; 9-Patagonic

mountain range.

and corroborated this hypothesis this time using panbiogeography; and added a new route to northwestern Argentina. This connection between the biotas of the Peripampasic Arc has also been shown for Asteraceae (Crisci et al. 2001), and some Arthropods (Maury 1973, Acosta 1989, 1993, Mattoni \& Acosta 1997, Acosta 2002, Ferretti et al. 2012).

Lichens are biological entities capable of growing on a wide range of substrates, natural or artificial, some species are substrate specific, while others are generalist (Holien 1996, Hauck \& Spribille 2005). The ubiquity of lichens, together with the small size of their propagules (spores, soredia and isidia) and their slow rates of evolution have resulted in a large number of species being distributed worldwide (Kärnefelt 1990, Galloway 2008). Jфrgensen (1983), based on the relatively low rate of evolution and the longevity of lichens, suggested that their 
distribution could be an indicator of historic geological events. Following the hypothesis of Jørgensen (1983) and the review by Rodriguez et al. (2011) of the saxicolous species of Usnea, we undertook a study of the lichens of Peripampasic Arc to establish their biogeographic connections within the sierras of the Arc and with the Andes and other mountain ranges of South America.

The aim of this work is to establish if the lichen biota of the Buenos Aires Sierras follows peripampasic distribution pattern and to establish its biogeographic linkages with the rest of the mountainous areas of Southern South America.

\section{MATERIALS AND METHODS}

Distributional data of 104 lichens species (Table I) were compiled from the collections of lichens of the Herbarium of the Instituto Spegazzini (LPS), the authors' personal herbaria, the GBIF (2017) database and from the literature (Osorio 1987, Stenroos et al. 1992, Athi 2000, Messuti \& Vobis 2002, Adler \& Calvelo 2007, Knudsen et al. 2008, Messuti \& de la Rosa 2009, Rodríguez 2011, de la Rosa \& Messuti 2014, Lavornia et al. 2016, Rodríguez et al. 2016). The species included were grouped by their substrate requirement (saxicolous, terricolous, lignicolous).

We compared the composition of eight areas, delineated by de la Sota et al. (2004) on the basis of orography, geology and regional biota, for distributional similarities (Figure 1); San Rafael-Mahuida, Area 3 of de la Sota et al. (2004) had no lichen records and it was not included in this study. For the comparison of the eight areas an out group was added (Isla Martín García) with its 47-strong epiphytic riparian forest lichenobiota and 3 species that are shared with rocky areas (García \& Rosato 2015). A data matrix of presence/absence of the 1359 records available was constructed for the 151 species, for the eight areas plus the out group (IMG).

For the analysis of $\beta$-diversity including the 104 species of the eight areas, and without including the out group, the Whittaker and Cody indices were selected to quantify and compare these sites because they are preferred in cases where differences in species richness between samples (or communities) need to be reflected in the measurement of $\beta$ diversity (Cardoso et al. 2009). For the single link cluster analysis PAST (Paleontological Statistics) version 3.17 software was used to observe the similarities between the sites. In the Cody index the difference between sites is shown, therefore their values are lower if the sites are similar and increase as the sites differentiate. On the other hand, in the Whittaker index the values range from 0 (sites that share all the species) to 1 (sites without shared species).

To measure the similarity between the proposed areas, the Jaccard index was selected because it is recommended for presenceabsence data (Real \& Vargas 1996). To avoid the 'double-zero problem' (species absent from two sites), the asymmetrical $\$ \phi$ rensen-Dice binary coefficient was selected, since it gives double weight to double presences, as absences may be due to various factors and does not necessarily reflect differences in the environment; doublepresence, on the contrary, is a strong indication of resemblance (Legendre \& Legendre 2012).

The maps where prepared with the use of the free software Quantum Gis and the shapefiles where downloaded from the IGN (Instituto Geográfico Nacional). 
Table I. Species presence in each of the 8 areas proposed and the outgroup. 1.Tandilia, 2.Ventania, 4.Pampean center's Hills, 5.Cuyan Pampeans hills and Precordillera, 6.North-West, 7.North-East, 8.Uruguay, 9.Patagonic mountain range, IMG. Isla Martín García (out group).

\begin{tabular}{|c|c|c|c|c|c|c|c|c|c|}
\hline Species & 1 & 2 & 4 & 5 & 6 & 7 & 8 & 9 & IMG \\
\hline Acarospora lorentzii & 1 & 1 & 1 & 0 & 1 & 0 & 1 & 0 & 0 \\
\hline Acarospora malmeana & 0 & 0 & 0 & 0 & 0 & 0 & 0 & 0 & 0 \\
\hline Acarospora rhabarbarina & 1 & 1 & 0 & 0 & 1 & 0 & 0 & 0 & 0 \\
\hline Acarospora xanthophana & 0 & 0 & 0 & 0 & 1 & 0 & 0 & 0 & 0 \\
\hline Bacidina pallidocarnea & 0 & 0 & 0 & 0 & 0 & 0 & 0 & 0 & 1 \\
\hline Brownliella cinnabarina & 1 & 1 & 0 & 0 & 0 & 0 & 1 & 1 & 0 \\
\hline Buellia glaucescens & 1 & 1 & 0 & 0 & 0 & 0 & 0 & 0 & 0 \\
\hline Buellia punctatula & 1 & 0 & 0 & 0 & 0 & 0 & 0 & 0 & 0 \\
\hline Buellia stellulata & 0 & 1 & 0 & 0 & 0 & 0 & 1 & 0 & 0 \\
\hline Caloplaca americana & 0 & 1 & 0 & 0 & 0 & 0 & 0 & 0 & 0 \\
\hline Caloplaca cerina & 0 & 0 & 0 & 0 & 0 & 0 & 0 & 0 & 1 \\
\hline Caloplaca crocea & 0 & 0 & 0 & 0 & 0 & 0 & 0 & 0 & 1 \\
\hline Caloplaca microphyllina & 0 & 1 & 0 & 0 & 0 & 0 & 0 & 1 & 0 \\
\hline Caloplaca puiggarii & 0 & 1 & 0 & 0 & 0 & 0 & 0 & 0 & 0 \\
\hline Caloplaca rugulosa & 1 & 1 & 0 & 0 & 0 & 0 & 0 & 0 & 0 \\
\hline Candelaria concolor & 1 & 1 & 1 & 0 & 1 & 0 & 1 & 1 & 0 \\
\hline Candelaria fibrosa & 1 & 0 & 1 & 0 & 1 & 0 & 1 & 0 & 1 \\
\hline Candelariella aurella & 0 & 1 & 0 & 0 & 0 & 0 & 0 & 0 & 0 \\
\hline Canoparmelia austroamericana & 0 & 0 & 0 & 0 & 0 & 0 & 0 & 0 & 1 \\
\hline Canoparmelia crozalsiana & 0 & 0 & 0 & 0 & 0 & 0 & 0 & 0 & 1 \\
\hline Canoparmelia rupicola & 0 & 1 & 0 & 0 & 0 & 0 & 0 & 0 & 0 \\
\hline Canoparmelia texana & 0 & 0 & 0 & 0 & 0 & 0 & 0 & 0 & 1 \\
\hline Carbonea latypizodes & 0 & 1 & 0 & 0 & 0 & 0 & 1 & 0 & 0 \\
\hline Catillaria chalybaeoides & 1 & 0 & 0 & 0 & 0 & 0 & 0 & 0 & 0 \\
\hline Chrysothrix candelaris & 1 & 0 & 0 & 0 & 0 & 0 & 1 & 1 & 0 \\
\hline Chrysotrix candelaris & 0 & 0 & 0 & 0 & 0 & 0 & 0 & 0 & 1 \\
\hline Cladia aggregata & 1 & 1 & 0 & 0 & 1 & 1 & 1 & 1 & 0 \\
\hline Cladonia caespiticia & 1 & 0 & 0 & 0 & 0 & 0 & 0 & 0 & 0 \\
\hline Cladonia chlorophaea & 0 & 1 & 0 & 0 & 1 & 0 & 1 & 1 & 0 \\
\hline Cladonia furcata & 1 & 0 & 1 & 0 & 1 & 0 & 1 & 1 & 0 \\
\hline Cladonia litoralis & 1 & 0 & 0 & 0 & 0 & 0 & 0 & 0 & 0 \\
\hline Cladonia pleurota & 0 & 1 & 0 & 0 & 0 & 0 & 1 & 1 & 0 \\
\hline Cladonia pyxidata & 1 & 1 & 1 & 0 & 0 & 0 & 0 & 0 & 0 \\
\hline Cladonia subcariosa & 0 & 0 & 0 & 0 & 0 & 1 & 1 & 0 & 0 \\
\hline Cladonia subsquamosa & 0 & 0 & 1 & 0 & 1 & 1 & 1 & 0 & 0 \\
\hline Coenogonium isidiosum & 0 & 0 & 0 & 0 & 0 & 0 & 0 & 0 & 1 \\
\hline Collema subconveniens & 1 & 0 & 0 & 0 & 0 & 0 & 0 & 0 & 0 \\
\hline
\end{tabular}


Table I. Continuation

\begin{tabular}{|c|c|c|c|c|c|c|c|c|c|}
\hline Diploschistes actinostomus & 0 & 1 & 0 & 0 & 0 & 0 & 1 & 0 & 0 \\
\hline Diploschistes cinereocaesius & 0 & 1 & 1 & 0 & 1 & 0 & 1 & 0 & 0 \\
\hline Diploschistes diacapsis & 1 & 0 & 0 & 0 & 0 & 0 & 0 & 0 & 0 \\
\hline Diploschistes ochraceus & 0 & 1 & 0 & 0 & 0 & 0 & 0 & 0 & 0 \\
\hline Endocarpon pusillum & 1 & 0 & 0 & 0 & 0 & 0 & 0 & 0 & 0 \\
\hline Flavoparmelia exornata & 0 & 0 & 0 & 0 & 0 & 0 & 0 & 0 & 1 \\
\hline Flavoparmelia haysomii & 1 & 1 & 1 & 0 & 1 & 0 & 0 & 0 & 0 \\
\hline Flavoparmelia papillosa & 1 & 1 & 1 & 0 & 1 & 0 & 1 & 0 & 0 \\
\hline Flavoplaca austrocitrina & 1 & 1 & 0 & 0 & 0 & 0 & 0 & 0 & 0 \\
\hline Glyphis cicatricosa & 0 & 0 & 0 & 0 & 0 & 0 & 0 & 0 & 1 \\
\hline Graphis geraënsis & 0 & 0 & 0 & 0 & 0 & 0 & 0 & 0 & 1 \\
\hline Graphis submarginata & 0 & 0 & 0 & 0 & 0 & 0 & 0 & 0 & 1 \\
\hline Haematomma fenzlianum & 1 & 0 & 0 & 0 & 0 & 0 & 1 & 0 & 0 \\
\hline Haematomma persoonii & 0 & 0 & 0 & 0 & 0 & 0 & 0 & 0 & 1 \\
\hline Hafellia fraudans & 0 & 0 & 0 & 0 & 0 & 0 & 0 & 0 & 1 \\
\hline Hafellia parastata & 0 & 0 & 0 & 0 & 0 & 0 & 0 & 0 & 1 \\
\hline Heterodermia comosa & 0 & 0 & 0 & 0 & 0 & 0 & 0 & 0 & 1 \\
\hline Heterodermia diademata & 0 & 0 & 0 & 0 & 0 & 0 & 0 & 0 & 1 \\
\hline Heterodermia squamulosa & 0 & 1 & 0 & 0 & 1 & 0 & 1 & 0 & 0 \\
\hline Hyperphyscia adglutinata & 0 & 1 & 0 & 0 & 0 & 0 & 0 & 0 & 0 \\
\hline Hyperphyscia adglutinata & 0 & 0 & 0 & 0 & 0 & 0 & 0 & 0 & 1 \\
\hline Hyperphyscia syncolla & 1 & 1 & 0 & 0 & 0 & 0 & 0 & 0 & 0 \\
\hline Hyperphyscia syncolla & 0 & 0 & 0 & 0 & 0 & 0 & 0 & 0 & 1 \\
\hline Hypotrachyna livida & 1 & 0 & 0 & 0 & 1 & 1 & 1 & 0 & 0 \\
\hline Hypotrachyna osorioi & 1 & 1 & 1 & 0 & 0 & 0 & 1 & 0 & 0 \\
\hline Ingvariella bispora & 0 & 1 & 0 & 1 & 0 & 0 & 1 & 1 & 0 \\
\hline Lecanora farinacea & 0 & 1 & 1 & 0 & 1 & 0 & 1 & 1 & 0 \\
\hline Lecanora fusca & 1 & 1 & 0 & 0 & 0 & 0 & 1 & 0 & 0 \\
\hline Lecanora helva & 0 & 0 & 0 & 0 & 0 & 0 & 0 & 0 & 1 \\
\hline Lecanora microcarpa & 1 & 0 & 0 & 0 & 0 & 0 & 0 & 0 & 0 \\
\hline Lecanora tropica & 0 & 0 & 0 & 0 & 0 & 0 & 0 & 0 & 1 \\
\hline Lepraria gracilescens & 0 & 1 & 0 & 0 & 0 & 0 & 0 & 0 & 0 \\
\hline Leptogium azureum & 0 & 0 & 0 & 0 & 0 & 0 & 0 & 0 & 1 \\
\hline Leptogium cyanescens & 0 & 0 & 0 & 0 & 0 & 0 & 0 & 0 & 1 \\
\hline Malmiella leptoloma & 0 & 0 & 0 & 0 & 0 & 0 & 0 & 0 & 1 \\
\hline Normandina pulchella & 1 & 1 & 0 & 0 & 0 & 0 & 0 & 1 & 0 \\
\hline Ochrolechia tartarea & 1 & 0 & 0 & 0 & 0 & 0 & 0 & 0 & 0 \\
\hline Parmotrema austrosinense & 0 & 1 & 1 & 1 & 1 & 1 & 0 & 0 & 0 \\
\hline Parmotrema cetratum & 1 & 1 & 0 & 0 & 0 & 0 & 0 & 0 & 0 \\
\hline Parmotrema cetratum & 0 & 0 & 0 & 0 & 0 & 0 & 0 & 0 & 1 \\
\hline
\end{tabular}


Table I. Continuation

\begin{tabular}{|c|c|c|c|c|c|c|c|c|c|}
\hline Parmotrema conferendum & 1 & 0 & 0 & 0 & 1 & 0 & 0 & 0 & 0 \\
\hline Parmotrema eciliatum & 0 & 1 & 0 & 0 & 1 & 1 & 1 & 0 & 0 \\
\hline Parmotrema eciliatum & 0 & 0 & 0 & 0 & 0 & 0 & 0 & 0 & 1 \\
\hline Parmotrema fistulatum & 1 & 0 & 0 & 0 & 0 & 0 & 0 & 0 & 0 \\
\hline Parmotrema perlatum & 1 & 0 & 0 & 0 & 1 & 0 & 0 & 0 & 0 \\
\hline Parmotrema pseudobreviciliatum & 1 & 0 & 0 & 0 & 0 & 0 & 0 & 0 & 0 \\
\hline Parmotrema reticulatum & 1 & 1 & 1 & 0 & 0 & 0 & 0 & 0 & 0 \\
\hline Parmotrema reticulatum & 0 & 0 & 0 & 0 & 0 & 0 & 0 & 0 & 1 \\
\hline Parmotrema tandilense & 1 & 1 & 0 & 0 & 0 & 0 & 0 & 0 & 0 \\
\hline Parmotrema uruguense & 1 & 1 & 0 & 0 & 1 & 1 & 1 & 1 & 0 \\
\hline Parmotrema ventanicum & 1 & 1 & 1 & 0 & 0 & 0 & 0 & 0 & 0 \\
\hline Pertusaria patagonica & 1 & 1 & 0 & 0 & 0 & 0 & 0 & 1 & 0 \\
\hline Physcia aipolia & 0 & 0 & 0 & 0 & 0 & 0 & 0 & 0 & 1 \\
\hline Physcia alba & 0 & 0 & 0 & 0 & 0 & 0 & 0 & 0 & 1 \\
\hline Physcia cinerea & 1 & 0 & 0 & 0 & 0 & 0 & 0 & 0 & 0 \\
\hline Physcia convexella & 0 & 1 & 0 & 0 & 0 & 0 & 0 & 0 & 0 \\
\hline Physcia crispa & 0 & 0 & 0 & 0 & 0 & 0 & 0 & 0 & 1 \\
\hline Physcia erumpens & 0 & 0 & 0 & 0 & 0 & 0 & 0 & 0 & 1 \\
\hline Physcia phaeocarpa & 1 & 0 & 0 & 0 & 0 & 0 & 0 & 0 & 0 \\
\hline Physcia poncinsii & 0 & 1 & 1 & 0 & 0 & 0 & 0 & 1 & 0 \\
\hline Physcia rolfii & 0 & 0 & 0 & 0 & 0 & 0 & 0 & 0 & 1 \\
\hline Physcia sinuosa & 0 & 0 & 0 & 0 & 0 & 0 & 0 & 0 & 1 \\
\hline Physcia stellaris & 0 & 0 & 0 & 0 & 0 & 0 & 0 & 0 & 1 \\
\hline Physcia tribacia & 0 & 1 & 1 & 0 & 1 & 0 & 0 & 0 & 0 \\
\hline Physcia undulata & 1 & 1 & 1 & 0 & 0 & 0 & 0 & 0 & 0 \\
\hline Physcia undulata & 0 & 0 & 0 & 0 & 0 & 0 & 0 & 0 & 1 \\
\hline Physciella chloantha & 1 & 0 & 1 & 0 & 0 & 0 & 0 & 0 & 0 \\
\hline Porina nucula & 0 & 0 & 0 & 0 & 0 & 0 & 0 & 0 & 1 \\
\hline Psora icterica & 1 & 1 & 0 & 0 & 1 & 0 & 1 & 1 & 0 \\
\hline Punctelia borreri & 1 & 0 & 0 & 1 & 1 & 0 & 1 & 1 & 0 \\
\hline Punctelia colombiana & 1 & 0 & 1 & 0 & 1 & 1 & 0 & 0 & 0 \\
\hline Punctelia constantimontium & 1 & 0 & 0 & 0 & 1 & 0 & 1 & 0 & 0 \\
\hline Punctelia constantimontium & 0 & 0 & 0 & 0 & 0 & 0 & 0 & 0 & 1 \\
\hline Punctelia hypoleucites & 1 & 1 & 1 & 0 & 1 & 0 & 1 & 0 & 0 \\
\hline Punctelia hypoleucites & 0 & 0 & 0 & 0 & 0 & 0 & 0 & 0 & 1 \\
\hline Punctelia perreticulata & 1 & 1 & 0 & 0 & 0 & 0 & 0 & 0 & 0 \\
\hline Punctelia punctilla & 1 & 1 & 1 & 0 & 1 & 0 & 0 & 0 & 0 \\
\hline Punctelia punctilla & 0 & 0 & 0 & 0 & 0 & 0 & 0 & 0 & 1 \\
\hline Punctelia rudecta & 0 & 1 & 0 & 0 & 1 & 0 & 1 & 0 & 0 \\
\hline Punctelia semansiana & 1 & 1 & 1 & 0 & 1 & 0 & 1 & 0 & 0 \\
\hline
\end{tabular}


Table I. Continuation

\begin{tabular}{|c|c|c|c|c|c|c|c|c|c|}
\hline Punctelia subpraesignis & 1 & 1 & 1 & 0 & 1 & 0 & 1 & 0 & 0 \\
\hline Pyrenula pyrenuloides & 0 & 0 & 0 & 0 & 0 & 0 & 0 & 0 & 1 \\
\hline Pyxine berteriana & 0 & 0 & 0 & 0 & 0 & 0 & 0 & 0 & 1 \\
\hline Pyxine cocoës & 0 & 0 & 0 & 0 & 0 & 0 & 0 & 0 & 1 \\
\hline Pyxine subcinerea & 0 & 0 & 0 & 0 & 0 & 0 & 0 & 0 & 1 \\
\hline Ramalina aspera & 0 & 0 & 0 & 0 & 0 & 0 & 0 & 0 & 1 \\
\hline Ramalina celastri & 1 & 0 & 1 & 0 & 1 & 1 & 1 & 0 & 1 \\
\hline Ramalina peruviana & 0 & 0 & 0 & 0 & 0 & 0 & 0 & 0 & 1 \\
\hline Rhizocarpon disporum & 1 & 1 & 0 & 0 & 0 & 0 & 0 & 1 & 0 \\
\hline Rhizocarpon interferunulum & 0 & 1 & 0 & 0 & 0 & 0 & 0 & 0 & 0 \\
\hline Rhizocarpon superficiale & 0 & 1 & 0 & 0 & 0 & 0 & 0 & 0 & 0 \\
\hline Teloschistes chrysophthalmus & 0 & 1 & 1 & 0 & 1 & 1 & 1 & 0 & 1 \\
\hline Teloschistes exilis & 0 & 0 & 0 & 0 & 0 & 0 & 0 & 0 & 1 \\
\hline Tephromela atra & 0 & 1 & 0 & 0 & 0 & 0 & 1 & 1 & 0 \\
\hline Toninia sedifolia & 0 & 1 & 0 & 0 & 0 & 0 & 0 & 0 & 0 \\
\hline Umbilicaria haplocarpa & 0 & 1 & 0 & 0 & 1 & 0 & 0 & 0 & 0 \\
\hline Umbilicaria krempelhuberi & 1 & 1 & 0 & 0 & 0 & 0 & 0 & 0 & 0 \\
\hline Usnea amblyoclada & 1 & 1 & 1 & 0 & 1 & 0 & 1 & 1 & 0 \\
\hline Usnea densirostra & 1 & 1 & 0 & 0 & 0 & 0 & 1 & 1 & 0 \\
\hline Usnea exigua & 1 & 1 & 0 & 0 & 0 & 0 & 1 & 0 & 0 \\
\hline Usnea fastuosa & 1 & 1 & 0 & 0 & 0 & 0 & 1 & 0 & 0 \\
\hline Usnea strigosa & 0 & 0 & 0 & 0 & 0 & 0 & 0 & 0 & 1 \\
\hline Verrucaria aethiobola & 0 & 1 & 0 & 0 & 0 & 0 & 0 & 1 & 0 \\
\hline Xanthoparmelia conspersa & 1 & 1 & 1 & 0 & 1 & 0 & 1 & 1 & 0 \\
\hline Xanthoparmelia farinosa & 0 & 1 & 1 & 0 & 1 & 1 & 1 & 1 & 0 \\
\hline Xanthoparmelia hypopsila & 1 & 0 & 1 & 0 & 1 & 0 & 0 & 0 & 0 \\
\hline Xanthoparmelia microspora & 1 & 1 & 0 & 0 & 0 & 0 & 0 & 0 & 0 \\
\hline Xanthoparmelia saxeti & 0 & 1 & 0 & 0 & 0 & 0 & 0 & 0 & 0 \\
\hline Xanthoparmelia scabrosa & 0 & 1 & 0 & 0 & 1 & 0 & 0 & 1 & 0 \\
\hline Xanthoparmelia squamans & 0 & 1 & 0 & 0 & 0 & 0 & 0 & 0 & 0 \\
\hline Xanthoparmelia tinctina & 1 & 1 & 0 & 0 & 0 & 0 & 0 & 0 & 0 \\
\hline Xanthoparmelia ulcerosa & 0 & 1 & 1 & 0 & 1 & 0 & 1 & 1 & 0 \\
\hline Xanthoparmelia wrightiana & 1 & 1 & 1 & 0 & 1 & 0 & 1 & 0 & 0 \\
\hline Xanthoria parietina & 1 & 0 & 0 & 0 & 0 & 0 & 1 & 0 & 0 \\
\hline
\end{tabular}




\section{RESULTS}

Both the Dice (Table II) and Jaccard (Table III) similarity indices showed a similar relationship among the groups. There was a central group formed by $((((46) 8) 1) 2)(D=>0.5, J=>0.4)$. Within this, cluster 4 (Pampean center's Hills) and 6 (North-west) were the most similar $(D=0.676$ and $J=0.51$ ). Sites 9 (Patagonic mountain range), 7 (North-East) and 5 (Cuyan Pampeans hills and Precordillera) were grouped with the central cluster (Figures 2 and 3); the outgroup (IMG) was separated from the cluster of eight groups of the Arc.
The highest values of turnover (TO) using the Whittaker index (Table IV) were found between Area 5 and the rest, with Area 1 being the most different from Area 5. The lowest values of TO were between Areas 1 and 2, 6 and 8 and 4 and 6, with the last group with the lowest TO. TO calculated by using the Cody Index (Table V) showed highest differences between Areas 5 and 7 and Areas 1 and 2; the smallest was found between Areas 5 and 9 and 5 and 7 (the latter being the lowest of all), both of them outside of the Peripampasic Arc.

Table II. Asymmetrical binary coefficient of Sorensen-Dice, for the 9 areas and the 151 species.

\begin{tabular}{|c|c|c|c|c|c|c|c|c|c|}
\hline & $\mathbf{1}$ & $\mathbf{2}$ & $\mathbf{4}$ & $\mathbf{5}$ & $\mathbf{6}$ & $\mathbf{7}$ & $\mathbf{8}$ & $\mathbf{9}$ & IMG \\
\hline $\mathbf{1}$ & 1 & 0.551 & 0.458 & 0.029 & 0.476 & 0.132 & 0.495 & 0.311 & 0.035 \\
\hline $\mathbf{2}$ & & 1 & 0.462 & 0.053 & 0.496 & 0.143 & 0.564 & 0.449 & 0.016 \\
\hline $\mathbf{4}$ & & & 1 & 0.059 & 0.676 & 0.286 & 0.507 & 0.286 & 0.074 \\
\hline $\mathbf{5}$ & & & & 1 & 0.093 & 0.143 & 0.085 & 0.143 & 0.000 \\
\hline $\mathbf{6}$ & & & & & 1 & 0.392 & 0.667 & 0.400 & 0.067 \\
\hline $\mathbf{7}$ & & & & & & 1 & 0.327 & 0.167 & 0.066 \\
\hline $\mathbf{8}$ & & & & & & & 1 & 0.522 & 0.064 \\
\hline $\mathbf{9}$ & & & & & & & & 1 & 0 \\
\hline IMG & & & & & & & & & 1 \\
\hline
\end{tabular}

Table III. Similarity coefficient of Jaccard, for the 9 sites and the 151 species.

\begin{tabular}{|c|c|c|c|c|c|c|c|c|c|}
\hline & $\mathbf{1}$ & $\mathbf{2}$ & $\mathbf{4}$ & $\mathbf{5}$ & $\mathbf{6}$ & $\mathbf{7}$ & $\mathbf{8}$ & $\mathbf{9}$ & IMG \\
\hline $\mathbf{1}$ & 1 & 0.4 & 0.297 & 0.015 & 0.313 & 0.07 & 0.329 & 0.184 & 0.0177 \\
\hline $\mathbf{2}$ & & 1 & 0.3 & 0.027 & 0.329 & 0.077 & 0.393 & 0.289 & 0.008 \\
\hline $\mathbf{4}$ & & & 1 & 0.03 & 0.511 & 0.167 & 0.339 & 0.167 & 0.038 \\
\hline $\mathbf{5}$ & & & & 1 & 0.0488 & 0.077 & 0.044 & 0.077 & 0 \\
\hline $\mathbf{6}$ & & & & & 1 & 0.244 & 0.5 & 0.25 & 0.034 \\
\hline $\mathbf{7}$ & & & & & & 1 & 0.196 & 0.091 & 0.034 \\
\hline $\mathbf{8}$ & & & & & & & 1 & 0.353 & 0.033 \\
\hline $\mathbf{9}$ & & & & & & & & 1 & 0 \\
\hline IMG & & & & & & & & & 1 \\
\hline
\end{tabular}




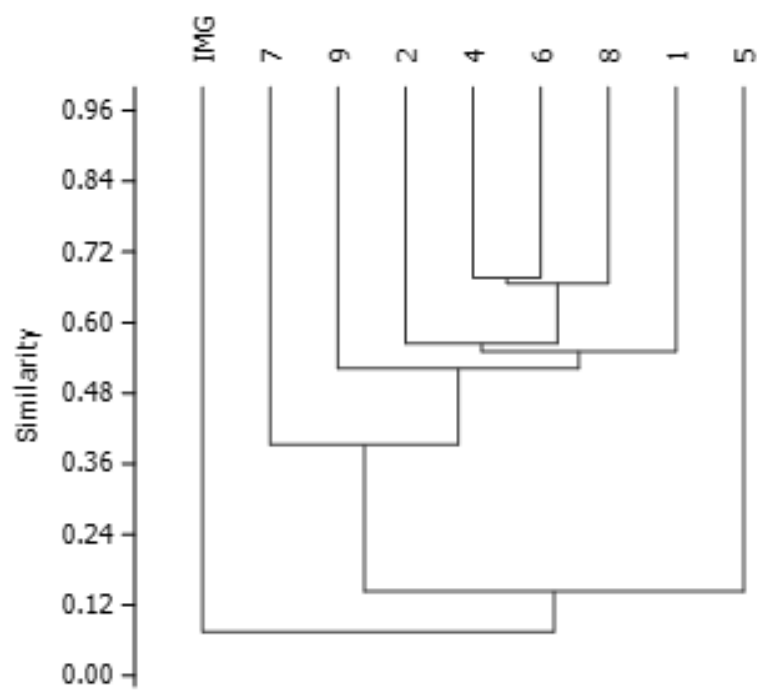

Figure 2. Cluster of the coefficient of Sorensen-Dice, for the 9 areas and the 151 species. Cophenetic correlation $=\mathbf{0 . 9 3 2}$.

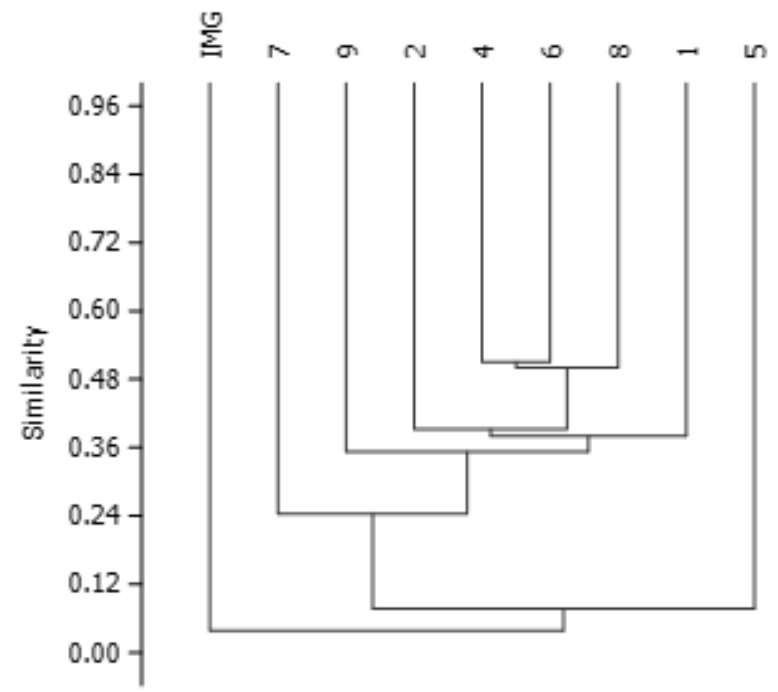

Figure 3. Cluster of coefficient of Jaccard, for the 9 areas and the 151 species. Cophenetic correlation= 0.935 .

Table IV. Index of $\beta$ diversity of Whittaker, for the 8 sites and the 104 species.

\begin{tabular}{|c|c|c|c|c|c|c|c|c|}
\hline & $\mathbf{1}$ & $\mathbf{2}$ & $\mathbf{4}$ & $\mathbf{5}$ & $\mathbf{6}$ & $\mathbf{7}$ & $\mathbf{8}$ & $\mathbf{9}$ \\
\hline $\mathbf{1}$ & 0 & 0.44286 & 0.54639 & 0.97101 & 0.5283 & 0.84615 & 0.4955 & 0.71111 \\
\hline $\mathbf{2}$ & & 0 & 0,54286 & 0.94805 & 0.50877 & 0.83721 & 0.42857 & 0.57143 \\
\hline $\mathbf{4}$ & & & 0 & 0.94118 & 0.32394 & 0.72093 & 0.5 & 0.70909 \\
\hline $\mathbf{5}$ & & & & 0 & 0.90698 & 0.86667 & 0.91667 & 0.85185 \\
\hline $\mathbf{6}$ & & & & & 0 & 0.1538 & 0.34118 & 0.625 \\
\hline $\mathbf{7}$ & & & & & & 0 & 0.64912 & 0.88889 \\
\hline $\mathbf{8}$ & & & & & & & 0 & 0.50725 \\
\hline $\mathbf{9}$ & & & & & & & & 0 \\
\hline
\end{tabular}

Table V. Index of $\beta$ diversity of Cody, for the 8 sites and the 104 species.

\begin{tabular}{|c|c|c|c|c|c|c|c|c|c|}
\hline & $\mathbf{1}$ & $\mathbf{2}$ & $\mathbf{4}$ & $\mathbf{5}$ & $\mathbf{6}$ & $\mathbf{7}$ & $\mathbf{8}$ & $\mathbf{9}$ \\
\hline $\mathbf{1}$ & 0 & 31 & 26.5 & 33.5 & 28 & 33 & 27.5 & 32 \\
\hline $\mathbf{2}$ & & 0 & 28.5 & 36.5 & 29 & 36 & 25.5 & 28 \\
\hline $\mathbf{4}$ & & & 0 & 16 & 11.5 & 15.5 & 19 & 19.5 \\
\hline $\mathbf{5}$ & & & & 0 & 19.5 & 6.5 & 22 & 11.5 \\
\hline $\mathbf{6}$ & & & & & 0 & 16 & 14.5 & 20 \\
\hline $\mathbf{7}$ & & & & & & 0 & 18.5 & 16 \\
\hline $\mathbf{8}$ & & & & & & & 0 & 17.5 \\
\hline $\mathbf{9}$ & & & & & & & & 0 \\
\hline
\end{tabular}




\section{DISCUSSION}

Hicken (1919) and Brade (1942) have postulated the existence of a biogeographical dispersal route of vascular plants from the Andes to Brazil, through the Pampean ranges, Ventania, Tandilia, and Uruguay up to the south-eastern Brazilian mountains. This has been confirmed by several studies (de la Sota 1985, de la Sota et al. 2004, Ferretti et al. 2012, 2014 Arana et al. 2013). This is the first time an analysis of this route encompassing the lichen biota of southern South America has been carried out.

A great similarity is observed between Areas 2 (Ventania) and 1 (Tandilia), as it has been observed by other authors and for various species, this close union is not only because of the proximity between them, but because it is part of one of the routes of the Peripampasic Arc (Cabrera \& Willink 1973, Frangi \& Bottino 1995, Acosta 2002, Rodríguez \& Estrabou 2008, Ferretti et al. 2012, Arana et al. 2013, Culebra Mason et al. 2017). Both analyses of similarity have shown that there is a strong relation between the biotas from Ventania and Tandilia, which in turn is linked to the biotas of Uruguay, the Pampean Sierras and north-west Argentina, corresponding to the Peripampasic Arc proposed by Frenguelli (1950). The $\beta$ diversity analyses show a lower turnover between the sites within the Peripampasic Arc and with those outside it, such as Patagonia and the pre-Cordillera. This could be explained by the fact that the dispersion range is variable among species, so although there is a relationship between the biota, the dispersal capacities of each species will allow some species to be present at all sites while others will not be present. As it has been observed for other organisms (de la Sota 1985, de la Sota et al. 2004, Ferretti et al. 2012, 2014, Arana et al. 2013), the link between the biotas from the Peripampasic Arc is evident, although there is also some indication of relations with the biota that is outside it (de la Sota et al. 2014).
In the Ventania area, the basin was tectonically active from Lower to Upper Palaeozoic (Sellés-Martínez 2001). Tandilia, on the other hand, was part of the Rio de La Plata craton (together with north-eastern Argentina, eastern Paraguay, Uruguay and south-eastern Brazil) before the end of the Precambrian (570 Ma) (Pankhurst et al. 2003, Rapela et al. 2007). Lichens belong to a very ancient group, some of them even present from the Early Devonian (Taylor et al. 1997, Karatygin et al. 2009), many species have a low mutation rate and a very extended life, with some species even following a Gondwanan distribution which indicates their presence prior to the separation of the continents (Rikkinen \& Poinar 2002, Galloway 2008). Therefore, lichens could have occupied these mountain ranges and from there reached the rest of the Peripampasic Arc; unfortunately, there is little fossil evidence that can corroborate this assertion.

The distributions of the biota of the southern South America were affected mainly by climatic and geomorphological phenomena that began during the second part of the Tertiary: during the marine transgression, the lands that emerged corresponded to the mountain ranges of Tandilia, Ventania, Pampean and Subandean (Ortíz-Jaureguizar \& Cladera 2006). The other major event took place from the Miocene to Pliocene, when the climate changed and became drier in southern South America due to the slow rise of the Andean chain and the cold Humboldt Current that intensified aridity (Villagrán \& Hinojosa 1997, Gregory-Wodzicki 2000, Zachos et al. 2001, Crisci et al. 2001, Ferretti et al. 2012, 2014). De la Sota $(1967,1972,1973,1985)$ established in numerous works that the mountains of Buenos Aires and Sierras Pampeanas are intermediary stations in the migration between the AndeanPampean biotas and the Australantartic and Austrobrasilean biotas. This supports the existence of an ancestral biota fragmented by tectonic events or climatic changes (Crisci et al. 2001, Arana et al. 2013). Given the evidence of this 
biota fragmentation along the Peripampasic Arc by natural events, it is not far-fetched to assume that the lichen biota that existed at that time also suffered the same events of fragmentation. The Peripampasic Arc differs from its surroundings in being a rocky structure surrounded by a matrix of grasslands and forests (Cabrera \& Willink 1973), many of the lichen species depend on a rocky substratum, so they are unable to grow in the environments that surround the mountains, as was postulated for ferns (de la Sota 1967), Therefore, the majority of species will be dispersed only between the components of the Peripampasic Arc and with other mountain ranges.

Outside the Peripampasic Arc there are other areas that also show links, although with less connection, possibly due to the geographical distances, barriers and climatic conditions that make even anemochory dispersion difficult (Heinken 1999, Muñoz et al. 2004). There is also a relationship with the austral biota (Area 9), as observed for Pteridophytes (de la Sota et al. 2004); in this case, the mesoclimatic characteristics of the sierras of Buenos Aires favour the establishment of species from colder climates (Kristensen \& Frangi 1995, 1996). This similarity between the groups of lichens and Pteridophytes can be due to their similar requirements (both groups of saxicolous species require rock as a substrate) (Brodo 1973, Barrington 1993, Tuomisto \& Ruokolainen 1994, Shirazi et al. 1996) and are dependent on the wind to transport their reproduction structures (Ingold 1971, Pyatt 1973, Geiger et al. 2007, Noblin et al. 2012). Area 7 is peripherial, showing a little relationship with the Peripampasic Arc, although it is far away and possibly related to the lichen biota of southern Brazil and Paraguay (de la Sota et al. 2004). In this type of tropical environments, the vegetation of vascular plants usually covers the rocky outcrops, leaving little space for the saxicolous lichen, which also explains the low richness of the area. On the other hand, the separation of Area 5 is striking, since it is located in the Peripampasic Arc, but in this case the distance in terms of its biota can be explained by the lack of references of lichen that exist for this area (Liberatore et al. 2002). Although there are some species that can grow on both rock and bark, the inclusion of the external group (IMG) shows that there is a great difference between the biota of the areas within the Peripampasic Arc and those outside of this dispersal route.

\section{CONCLUSION}

In this first analysis of the lichen biota on Peripampasic Arc, the lack of subgroups between the Areas studied suggest the importance of this Arc for the distribution of these lichens, strongly implying the Arc as a functional unit for their dispersion.

The lichen biota of the Peripampasic Arc may have been fragmented by natural events, being separated by large extensions of flat land, but maintaining a relationship between them and showing the existence of relationships with other lichen biotas existing outside this arc.

There are great gaps in the knowledge of the lichens of Argentina which make difficult the understanding of their dispersal patterns. Nonetheless this preliminary analysis on the basis of both bibliography records and collections (both from public and private herbariums), for the first time, allows to discern a general pattern, which resemble the ones proposed for other organism with similar habitat requirement. Further studies of the lichen biota of this area, will fill this gap, allowing a better understanding of the biogeographical relation of the South American lichen biota.

\section{Acknowledgments}

We want to thank Federico Lozano, Vilma Rosato and to the anonymous reviewers who with their contributions improved this manuscript. This research did not receive 
any specific grant from funding agencies in the public, commercial, or not-for-profit sectors.

\section{REFERENCES}

AAGESEN L, SZUMIK CA, ZULOAGA FO \& MORRONE O. 2009. Quantitative biogeography in the South America highlands-recognizing the Altoandina, Puna and Prepuna through the study of Poaceae. Cladistic 25: 295-310.

ACOSTA LE. 1989. La fauna de escorpiones y opiliones (Arachnida) de la provincia de Córdoba. PhD Thesis, Facultad de Ciencias Exactas, Físicas y Naturales: Universidad Nacional de Córdoba, 333 p.

ACOSTA LE. 1993. Escorpiones y opiliones de la provincia de Córdoba (Argentina): diversidad y zoogeografía. Bull Soc Neuchât Sci Nat 116: 11-17.

ACOSTA LE. 2002. Patrones zoogeográficos de los opiliones argentinos (Arachnida: Opiliones). Rev Iber Aracnol 6: 69-84.

ADLER M \& CALVELO S. 2007. Ampliación de las distribuciones de especies de Parmeliaceae (Ascomycota Liquenizados) en la República Argentina. Bol Soc Argent Bot 42: 1-11.

APTROOT A \& JAMES PW. 2002. Monitoring lichens on monuments. In: Nimis PL et al. (Eds). Monitoring with Lichens-Monitoring Lichens, Netherlands: Springer, p. 239-253.

ARANA MD, PONCE M, MORRONE JJ \& OGGERO AJ. 2013. Patrones biogeográficos de los helechos de las Sierras de Córdoba (Argentina) y sus Implicancias en la conservación. Gayana Bot 70: 307-327.

ATHI T. 2000. Cladoniaceae. Fl. Neotrop. Monogr. 78. New York: New York Botanical Garden Press, p. 362.

BARRINGTON DS. 1993. Ecological and Historical Factors in Fern Biogeography. J Biogeogr 20: 275-279.

BRADE AC. 1942. A composição da flora do Itatiaia. Rodriguésia 6: 29-43.

BRODO IM. 1973. Substrate ecology. In: Ahmadjian V and Hale ME (Eds.). The lichens, New York and London: Academic press, INC, p. 401-441.

CABRERA A \& WILLINK A. 1973. Biogeografía de América Latina. Washington, DC: Organization of American States (OAS), p. 122.

CABRERA AL. 1938. Revisión de las Anacardiaceas austroamericanas. Rev Mus La Plata Botánica 2: 3-63.

CARDOSO P, BORGES PAV \& VEECH JA. 2009. Testing the performance of beta diversity measures based on incidence data: The robustness to undersampling. Divers Distrib 15: 1081-1090.
CRISCI JV, FREIRE SE, SANCHO G \& KATINAS L. 2001. Historical biogeography of the Asteraceae from Tandilia and Ventania Mountain ranges (Buenos Aires, Argentina). Caldasia 23: 21-41.

CULEBRA MASON S, SGARBI C, CHILA COVACHINA J, PEÑA JM, DUBROVSKY BERENSZTEIN N, MARGARÍA C \& RICCI M. 2017. Acromyrmex Mayr (Hymenoptera: Formicidae: Myrmicinae): patrones de distribución de las especies en la provincia de Buenos Aires, Argentina. Rev Mus Argentino Cienc Nat 19(2): 185-199.

DARWIN CR. 1846. Geological observations on South America. Being the third part of the geology of the voyage of the Beagle, under the command of Capt. Fitzroy, R.N. during the years 1832 to 1836, London: Smith Elder and Co, $457 \mathrm{p}$.

DE LA ROSA IN \& MESSUTI MI. 2014. Las especies del género Lecanora (Ascomycota, Lecanoraceae) en la provincia de Tucumán (Argentina). Lilloa 51: 33-45.

DE LA SOTA ER. 1967. Composición, origen y vinculaciones de la flora Pteridológica de las sierras de Buenos Aires (Argentina). Bol Soc Argent Bot 11: 105-128.

DE LA SOTA ER. 1972. Notas sobre las especies Austrosudamericanas del género Blechnum L., III, El género Blechnum en la provincia de Buenos Aires. Bol Soc Argent Bot 14: 177-197.

DE LA SOTA ER. 1973. La distribución geográfica de las Pteridófitas en el cono sur de América meridional. Bol Soc Argent Bot 15: 23-34.

DE LA SOTA ER. 1985. Las pteridofitas de la provincia de La Pampa, Argentina. Rev Fac Agro Uni Nac La Pampa 1: 23-34.

DE LA SOTA ER, GUIDICE GE, PONCE M, RAMOS GIACOSA JP \& ARTURI M. 2004. Relaciones Fitogeográficas de la flora Pteridofítica Serrana Bonaerense. Bol Soc Argent Bot 39: 181-194.

FERRETTI N, GONZÁLEZ A \& PÉREZ-MILES F. 2012. Historical biogeography of Mygalomorph spiders from the peripampasic orogenic arc based on track analysis and PAE as a panbiogeographical tool. Syst Biodivers 10: 179-193.

FERRETTI N, GONZÁLEZ A \& PÉREZ-MILES F. 2014. Historical relationships among Argentinean biogeographic provinces based on Mygalomorph spider distribution data (Araneae: Mygalomorphae). Stud Neotrop Fauna Environ 49: 1-10.

FRANGI JL \& BOTTINO O. 1995. Comunidades vegetales de la Sierra de la Ventana, Provincia de Buenos Aires, Argentina. Rev Fac Agro (La Plata) 71 (1): 93-133.

FRENGUELLI J. 1950. Rasgos generales de la morfología y la geología de la provincia de Buenos Aires. Lab. Ensayos Materiales Invest Tecnol (LEMIT) 33(2): 1-72. 
GALLOWAY D. 2008. Lichen Biogeography. In: Nash TH III (Ed), Lichen Biology. Cambridge: Cambridge University Press, p. 315-335.

GARCíA R. 2018. Contribución al estudio de la liquenobiota del patrimonio edilicio de la provincia de Buenos Aires (Argentina). PhD Tesis. Argentina: Universidad Nacional de La Plata, 213 p.

GARCíA R \& ROSATO V. 2015. Líquenes (Ascomycota liquenizados) de la Reserva Natural Isla Martín García. Nuevos registros para la provincia de Buenos Aires y para Argentina. Lilloa 52 (1): 31-39.

GBIF. 2017. Global Biodiversity Information Facility (on line) https://www.gbif.org (accessed 10/10/2017).

GEIGER JMO, RANKER TA, RAMP NEALE JM \& KLIMAS ST. 2007. Molecular biogeography and origins of the Hawaiian fern flora. Brittonia 59: 142-158.

GREGORY-WODZICKI KM. 2000. Uplift history of the central and northern Andes: a review. Geol Soc Am Bull 112: 1091-1105.

GRELA I. 2004. Geografía floristica de las especies arboreas de Uruguay: propuesta para la delimitación de Dendrofloras. Ms thesis. PEDECIBA, Uruguay, Montevideo: Universidad de la Republica, $93 \mathrm{p}$.

HAUCK M \& SPRIBILLE T. 2005. The significance of precipitation and substrate chemistry for epiphytic lichen diversity in spruce-fir forests of the Salish Mountains, Montana. Flora 200: 547-562.

HEINKEN T. 1999. Dispersal Patterns of Terricolous Lichens by Thallus Fragments. Lichenologist 31: 603-612.

HICKEN CM. 1919. La migración de los helechos en la flora de Tucumán. San Miguel de Tucumán, Argentina: Primera Reunión Nacional de la Sociedad Argentina de Ciencias Naturales, p. 187-209.

HOLIEN H. 1996. Influence of site and stand factors on the distribution of crustose lichens of the Caliciales in a suboceanic spruce forest area in central Norway. Lichenologist 28: 315-330.

INGOLD CT. 1971. Fungal spores. Clarendon Press, Oxford, p. 1093

JØRGENSEN PM. 1983. Distribution patterns of lichens in the Pacific region. Austral J Bot, Suppl Ser 10: 43-66.

KARATYGIN IV, SNIGIREVSKAYA NS \& VIKULIN SV. 2009. The most ancient terrestrial lichen Winfrenatia reticulata: a new find and new interpretation. Paleontol J 43: 107-114.

KÄRNEFELT I. 1990. Evidence of a slow evolutionary change in the speciation of lichens. Bibl Lichenol 38: 291-306.

KNUDSEN K, ELIX JA \& REEB V. 2008. A Preliminary Study of the Genera Acarospora and Pleopsidium in South America. Opusc Philolichenum 5: 1-22.
KRISTENSEN MJ \& FRANGI JL. 1995. Mesoclimas de pastizales serranos. Ecol Aust 5: 55-64.

KRISTENSEN MJ \& FRANGI JL. 1996. Mesoclimas de roquedales serranos. Ecol Aust 6: 115-122.

LAVORNIA JM, KRISTENSEN MJ \& ROSATO VG. 2016. Clave de identificación de líquenes saxicolas del Paisaje Protegido "La Poligonal" (Sistema de Tandilia, Buenos Aires). Rev Mus Argentino Cienc Nat 18: 107-115.

LEGENDRE P \& LEGENDRE L. 2012. Numerical Ecology. Amsterdam: Elsiever, $1006 \mathrm{p}$.

LIBERATORES, GARIBOTTI G \& CALVELOS. 2002. Phytogeography of Argentinean lichens. Bibl Lichenol 82: 221-234.

MATTONI CI \& ACOSTA LE. 1997. Scorpions of the insular Sierras in the Llanos District (Province of La Rioja, Argentina) and their zoogeographical links. Biogeographica 73: 67-80.

MAURY EA. 1973. Los escorpiones de los sistemas serranos de la provincia de Buenos Aires. Physis 32: 351-371.

MESSUTI MI \& DE LA ROSA IN. 2009. Notes on the genus Haematomma (Ascomycota, Lecanoraceae) in Argentina. Darwiniana 47: 297-308.

MESSUTI MI \& VOBIS G. 2002. Lichenes Pertusariales: Coccotremataceae, Megasporaceae y Pertusariaceae. In: Guarrera SA et al. (Eds), Flora Criptogámica de Tierra del Fuego Buenos Aires, Argentina: CONICET, 106 p.

MÚÑOZ J, FELICÍSIMO AM, CABEZAS F, BURGAZ AR \& MARTÍNEZ I. 2004. Wind as a Long-Distance Dispersal Vehicle in the Southern Hemisphere. Science 304: 1144.

NAVARRO FR, CUEZZO F, GOLOBOFF P, SZUMIK C, LIZARRALDE DE GROSSO M \& QUINTANA G. 2009. Can insect data be used to infer areas of endemism? An example from the Yungas of Argentina. Rev Chil Hist Nat 82: 507-522.

NOBLIN X, ROJAS NO, WESTBROOK J, LLORENS C, ARGENTINA M \& DUMAIS J. 2012. The Fern Sporangium: A Unique Catapult. Science 1322.

NORI J, DÍAZ GÓMEZ JM \& LEYNAUD GC. 2011. Biogeographic regions of Central Argentina based on snake distribution: evaluating two different methodological approaches. J Nat Hist 45: 1005-1020.

ORTíz-JAUREgUIZAR E \& CLADERA GA. 2006. Paleoenvironmental evolution of southern South America during the Cenozoic. J Arid Environ 66: 498-532.

OSORIO HS. 1987. Contribution to the lichen flora of Argentina XVI. Lichens from Sierra de la Ventana, Buenos Aires province. Com Bot Mus Montevideo 78: 1-11.

PANKHURST RJ, RAMOS A \& LINARES E. 2003. Antiquity and evolution of the Rio de la Plata craton in Tandilia, southern Buenos Aires province, Argentina. J S Am Earth Sci 16: 5-13. 
PINTO DA ROCHA R, DA SILVA MB \& BRAGAGNOLO C. 2005. Faunistic similarity and historic biogeography of the harvestmen of southern and southeastern Atlantic rain forest of Brazil. J Arachnol 33: 290-299.

PYATT FB. 1973. Lichen propagules. In: Ahmadjian V and Hale ME (Eds). The lichens. New York: Academic Press, p. 117-145.

RAPELA CW, PANKHURST RJ, CASQUET C, FANNING CM, BALDO EG, GONZÁLEZ-CASADO JM, GALINDO C \& DAHLQUIST J. 2007. The Rio de la Plata craton and the assembly of SW Gondwana. Earth Sci Review 83: 49-82.

REAL R \& VARGAS JM. 1996. The probabilistic basis of Jaccard's index of similarity. Syst Biol 45: 380-385.

RIKKINEN J \& POINAR GO. 2002. Fossilised Anzia (Lecanorales, lichen-forming Ascomycota) from European tertiary amber. Mycol Res 106(8): 984-990.

RINGUELET RA. 1961. Rasgos fundamentales de la zoogeografía de la Argentina. Physis 22: 151-170.

ROdRíguEZ JM. 2011. El género Usnea (Ascomycetes liquenizados) en Argentina: estudio sistemático y biogeográfico. PhD Thesis. Facultad de ciencias Exactas, Físicas y Naturales: Universidad Nacional de Córdoba, $217 \mathrm{p}$.

RODRÍGUEZ JM \& ESTRABOU C. 2008. Usnea amblyoclada "barba de piedra" (Ascomycetes liquenizados) en Argentina. Bol Soc Argent Bot 43: 221-225.

RODRÍGUEZ JM, ESTRABOU C, TRUONG C \& CLERC P. 2011. The saxicolous species of the genus Usnea subgenus Usnea (Parmeliaceae) in Argentina and Uruguay. Bryologist 114: 504-525.

RODRÍGUEZ JM, HERNÁNDEZ JM, FILIPPINI E, CAÑAS M \& ESTRABOU C. 2016. Nuevas citas de macrolíquenes para Argentina y ampliaciones de distribución en el centro del país. Bol Soc Argent Bot 51: 405-417.

SELLÉS-MARTÍNEZ J. 2001. The geology of Ventania (Buenos Aires province, Argentina). J Iber Geol 27: 43-69.

SHIRAZI AM, MUIR PS \& MCCUNE B. 1996. Environmental Factors Influencing the Distribution of the Lichens Lobaria oregana and L. pulmonaria. Bryologist 99: 12-18.

STENROOS S, FERRARO LI \& AHTI T. 1992. Lichenes Lecanorales: Cladoniaceae. In: Guarrera SA et al. (Eds). Flora Criptogámica de Tierra del Fuego, Buenos Aires, Argentina: CONICET, $111 \mathrm{p}$.

SZUMIK C ET AL. 2007. Biogeografía del norte argentino (paralelos 21 a 32): primer ensayo utilizando vertebrados, insectos y plantas. Darwiniana 45: 49-51.

TAYLOR TN, HASS H \& KERP H. 1997. A cyanolichen from the Lower Devonian Rhynie Chert Am J Bot 84: 992-1004.
TERUGGI M \& KILMURRAY JT. 1975. Geología de la provincia de Buenos Aires. In: Relatorio VI Congreso Geológico Argentino, Bahía Blanca, Argentina, p. 55-77.

TUOMISTO H \& RUOKOLAINEN K. 1994. Distribution of Pteridophyta and Melastomataceae along an edaphic gradient in an Amazonian rain forest. J Veg Sci 5: 25-34.

VILLAGRÁN C \& HINOJOSA LF. 1997. Historia de los bosques de Sudamérica II: Análisis fitogeográfico. Rev Chil Hist Nat 70: 241-267.

ZACHOS J, PAGANI M, SLOAN L, THOMAS E \& BILLUPS K. 2001. Trends, rhythms, and aberrations in global climate $65 \mathrm{Ma}$ to Present. Science 292: 686-693.

\section{How to cite}

GARCíA RA \& DEL PALACIO A. 2021. Peripampasic Arc: a route of dispersion for lichens. An Acad Bras Cienc 93: e20191208. DOI 10.1590/00013765202120191208 .

Manuscript received on October 03, 2019;

accepted for publication on January 12, 2020

\section{RENATO A. GARCÍA ${ }^{1,2}$}

https://orcid.org/0000-0002-6040-2250

\begin{abstract}
ALEJANDRO DEL PALACIO ${ }^{1,2}$
https://orcid.org/0000-0001-9808-0376

${ }^{1}$ Universidad Nacional de Avellaneda, Laboratorio de Biodiversidad y Genética Ambiental (Biogea), Mario

Bravo 1460, Piñeyro 1870, Buenos Aires, Argentina

${ }^{2}$ Consejo Nacional de Investigaciones Científicas y Técnicas (CONICET), Godoy Cruz, 2290,

C1425FQB CABA, República Argentina
\end{abstract}

Correspondence to: Renato Andrés García

E-mail:garciarenato86@gmail.com

\section{Author contributions}

Renato A. García: Conceptualization, Investigation, Methodology, Writing - review \& editing.

Alejandro del Palacio: Investigation, Methodology, Formal analysis, Writing - review \& editing.

\section{(c) BY}

